\title{
Foreword: The PhilAnd Project
}

"The origin and early development of philosophy in tenth-century al-Andalus: the impact of ill-defined materials and channels of transmission" (hereafter, PhilAnd) is an Advanced Grant ERC project funded by the European Research Council and currently being conducted at UCLouvain and the Warburg Institute (University of London). ${ }^{1}$ PhilAnd aims to provide new insights into an important chapter in the history of Islamic speculative thinking. It is concerned with the time and the form under which philosophy - in the sense of a rational, scientific and comprehensive system to approach the reality of the world around us - appeared for the first time in al-Andalus, and with the role played by this formative stage in the history of philosophy as later developed in the Iberian Peninsula among the three monotheistic communities.

PhilAnd pursues three main objectives, namely:

(1) to determine whether the emergence of philosophy in al-Andalus did not significantly predate the time ordinarily acknowledged in modern scholarship;

(2) to establish whether the impact of this early phase on later developments of rational thinking in al-Andalus was not considerably greater than has usually been assumed thus far;

(3) to provide evidence in order to assess, on a scientific basis, the originality of the first Andalusi philosophers with respect to their predecessors in the Orient.

The project stands at the crossroads of several major lines of enquiry in modern scholarship: the overall history of Arabic sciences in al-Andalus, the libraries and cultural centres of al-Andalus, the interaction of politics, religion and science in the Peninsula, the common threads of Islamic and Jewish philosophy and mysticism in and outside the Peninsula, Greek-Arabic philosophy across the Mediterranean or more specifically in the context of Shī'ism and Ismāî̀lism, Arabic into Latin and the legacy of Arabic sciences in medieval Europe, the reception of Jewish literature in the Latin Middle Ages. Although it has been designed to develop and stimulate a network of collaborations with

1 ERC Grant Agreement number 740618 (under the European Union's H2O2O ERC MGA Programme). The project started in October 2017 and will extend to September 2023: https:// sites.uclouvain.be/erc-philand/. 
most of these lines of enquiry, PhilAnd is different from any of them all and is fundamentally original in two crucial respects.

First, it puts a major emphasis on the 4th/1oth century. This is a period that has often been disregarded by historians of Arab-Islamic philosophy concerned with al-Andalus on the assumption that philosophy in al-Andalus only emerged with the Jew Salomon Ibn Gabirol/Avicebron (d. 450/1058) in the

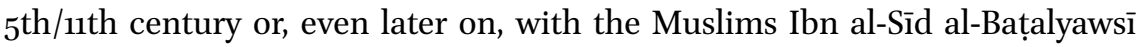
(d. 521/1127) and Ibn Bāğğa/Avempace (d. 533/1139) in the 6th/12th century. To a very large extent, the disregard of modern scholarship for the philosophical achievements of 4th/10th-century al-Andalus is the result of a series of confusions, misconceptions and erroneous dating touching three authors (or possibly group of authors, in one case) whose role in the transfer of philosophy between the Eastern and the Western parts of the dār al-islām was in all likelihood decisive, and who for this reason are at the core of the present exploration, namely: 1) the Ihwān al-Ṣafầ; 2) Ibn Masarra (d. 319/931); 3) Maslama b. Qāsim al-Qurțubī (d. 353/964).

Secondly, the project is resolutely focused on a major reevaluation of 'illdefined' material and channels of transmission. This also requires some justification. It has long been stressed that, among the sources which have been used by the author of the famous $\dot{G} \bar{a} y a t$ al-hakim/Picatrix, the three most important are: 1) the above-mentioned encyclopaedical corpus by the Ihwān al-Ṣafā'; 2) the corpus of works traditionally ascribed to the alchemist Ğābir b. Hayyān (supposed to have lived in the 2nd/8th century) and therefore usually referred to as 'Corpus Ğābirianum;' and 3) the 'Nabatean Agriculture' (al-Filäha l-nabatiyya) or, more exactly, the corpus of 'Nabatean' writings ascribed to Ibn Wahšiyya (written in 318/930-931), which is thus commonly referred to as the 'Nabatean Corpus.' These three corpora show a number of remarkable similarities, which incite study of them from a common perspective - something which has never been done so far. All three were produced in Orient. All three show a marked proclivity for disciplines such as astrology, magic and alchemy, which were regarded in the Middle Ages as part and parcel of the bulk of 'rational/philosophical sciences.' All three appear to have been significantly influenced by Ismāilism, although the relation with Ismā'îlism, and more generally with Shīism, remains to be clarified in each case. All three present themselves as compilations whose elaboration may have extended over several generations, posing to scholarship major problems of dating and authorship. All three are extremely syncretic compositions having in common a Neoplatonic background to which a huge quantity of material of various provenance - in particular Hermeticism, Șābianism and mysticism - has been superimposed. As a result of their Ismāîili bias, all three works show a common, 
and distinctly $b \bar{a} t \underline{t i n} \bar{\imath}$, manner to interpret the religious scriptures, and in particular the Qur'àn. Now, what is also particularly worth noting is that these three corpora of writings appear to have been introduced into al-Andalus about the very same period, and not at all impossibly by the same man, namely Maslama b. Qāsim al-Qurțubī, who is today generally acknowledged as the genuine author of the Rutbat al-hakim and the Gäyat al-hakim. How can we account for this fact? What prompted such a sudden interest in 4th/1oth-century alAndalus for doctrines so clearly at odds with the model imposed there by the Sunnī-Malikī traditionalists? Was there anything like an Ismāîìi $d a$ 'wa ('propaganda') in al-Andalus? Which was the role played by the regime itself in the reception of this type of knowledge? And how profoundly this introduction of heterodox material did affect the subsequent development of Neoplatonism and mysticism as cultivated in al-Andalus among the three monotheistic communities? These questions, largely remained unexplored thus far, are at the core of the present proposal.

In order to explore these issues with the best prospects of achieving groundbreaking results, eight sub-projects (SP) have been defined, which are briefly presented here. Five of these SP specifically deal with aspects of the three above-mentioned Eastern corpora - the 'Ğābirian' (SP1), the 'Ihwānian' (SP2), and the 'Nabatean' (SP3) - as well as with Ibn Masarra (SP4) and Maslama b. Qāsim al-Qurțubī (SP5). In addition to these five 'linear' SP, the project also includes three 'transversal' SP to reinforce its interdisciplinary and crosscultural approach, and to address wider and more complex cultural issues. Although in intimate connection with the former five SP, these latter three SP are conducted in the form of cross-disciplinary and international conferences to be held in a second phase of the project, namely:

- 'Power, religion and wisdom: bāținism between orthodoxy and heterodoxy in 1oth-century al-Andalus' (sp6, at the Institute for Advanced Study, Princeton);

- 'Interconnections between Jewish and Islamic rationalistic forms of thought during the 1oth-century' (SP7, at UCLouvain);

- 'Science and craft: the relations between the theoretical and practical sides of esoteric disciplines in al-Andalus and their link with craft' (SP8, at the Warburg Institute, University of London).

The following five articles are intended to give an idea of the research carried out as part of this project, although it is understood that each author takes personal responsibility for what he or she writes. Two contributions focus on the writings ascribed to the Ihwwān al-Ṣafāe. In one of them, Janne Mattila revisits the vexed issue of the kinship between the corpus of the Rasāil Ihwān al-Șafă with its about fifty epistles and al-Risāla l-ğāmi'a attributed to the same authors 
and supposed to constitute a sort of synthesis of the corpus. On the basis of close examination of internal references both in the Beirut edition and in the oldest manuscripts, Mattila concludes that the theory of a common authorship is no longer tenable. In the other study, which also invites the reader to reconsider the results of past scholarship, Godefroid de Callataÿ highlights the radically different way in which the Rasä il Ihwān al-Safä are considered in the Rutbat al-hakim and the $\dot{G} \bar{a}$ yat al-hakìm, suggesting that Maslama b. Qāsim al-Qurțubì had a copy of the Rasāil when he wrote the second of his 'twin' treatises on the occult, but not the first. Elaine van Dalen's contribution deals with al-Filäha l-nabațiyya. In contrast to the long-prevailing tendency to consider this work as of a limited value for the history of late-antique and early Islamic science, she argues that it contains rationally-based epistemological categories, methods of deductive reasoning, and a sense of empiricism that is judiciously applied to the field of botany and agriculture. For their part, Marion Dapsens and Sébastien Moureau present the critical edition, together with the English translation and a commentary, of an important alchemical treatise, namely an untitled epistle attributed to the Umayyad prince Hâlid b. Yazīd (d. ca 85/704). Additionally, they provide here for the first time the (partial) Latin version of this text, which they have recently identified. The last contribution of this dossier, by José Bellver, is focused on a codex preserved in Tunis, the only known extant manuscript presenting a complete copy of Ptolemy's Almagest in Ishāa/ Tābit version. Bellver's study is substantially focused on a marginal note of this manuscript which provides new information on the history of libraries and the transfer of books in al-Andalus.

Godefroid de Callatä̈ | ORCID: 0000-0001-6712-1999

Principal Investigator of PhilAnd, UCLouvain,

Louvain-la-Neuve, Belgique

godefroid.decallatay@uclouvain.be 